\title{
Preface
}

THIS BOOK is about the relation between political power and the national economy during the first decade of a greatly expanded British Empire. It investigates how an industrializing and newly ascendant state, overwhelmingly victorious in the Seven Years War, grappled with the fiscal, economic, political, and perceptual imperatives of its triumph. I am interested in how, in the aftermath of an exhausting yet successful war, macroeconomic and political transitions shaped some of the most important problems, possibilities, and policies of dominion. The book is not a comprehensive reconstruction of the politics and economics of empire in the mid-eighteenth century. Rather, it is a rethinking of some of the central historiographic tenets of imperial decision making in the 1760 s and 1770 .

The story opens in 1763 , when Britain's victory in the Seven Years War gained it dominion over lands as vast and disparate as India and Canada, as tiny and scattered as Tobago and Senegal. It closes in 1773, when Parliament wrested primary control of the eastern subcontinent from the East India Company and, as compensation, allowed the great trading concern to consign 105 , ooo pounds of taxable tea to the port of Boston. In the ten years between the Peace of Paris and the Boston Tea Party, British ministers, members of Parliament, and the political nation faced a series of novel and urgent challenges.

As government officials and others apprehended them, these challenges were conditioned by the country's recent experience of international combat. Some dilemmas involved fiscal exigency: how, in the war's wake, to pay for victory and for the military and administrative responsi- 
bilities that accompanied the nation's newfound global position. Related problems concerned political economy: how to promote domestic economic growth, especially manufacturing capabilities, in an enlarged commercial empire. These problems were, as for other states at other times, closely intertwined. In $176_{3}$ Britons understood that the nation's global position was tightly bound to its transforming economy. This collective realization continued to influence imperial policymaking.

Broadly viewed, these imperatives of empire-with their attendant risks, responsibilities, and rewards-were not unlike those experienced by Americans and Russians in the wake of the Second World War or even by Japan in the aftermath of a different kind of global contest in the 1980 os. Victory confronts individual states with the pressing geopolitical and economic demands of international authority. Founded on both power and plenty, global success also breeds political and perceptual transition at home. In each of these countries, governing elites and the larger citizenry struggle to decide who ultimately should superintend their nations' new strength. These societies have also tried to come to terms conceptually with their status and prosperity. In doing so, most have experienced an imperial schizophrenia, an often tempestuous blending of ambition and angst regarding the future. In Britain after the Seven Years War-as in the United States after World War IIthese collective and conflicted perspectives influenced national strategy.

My reconstruction of policymaking in the first British empire demands an integrated approach-one that reconstitutes imperial politics and economics as well as the dynamic between them. Oddly enough, this approach has few historiographic ancestors. Several scholars of military conflict have scrutinized Britain's involvement in the Seven Years War. A much larger group of historians has studied the war's colonial consequences. A few researchers have looked outward from Whitehall and Westminster to investigate the political rationale behind particular decisions involving the colonies. Students of eighteenth-century England have thus been left with an incomplete set of disaggregated analyses of the war and of specific decisions of empire made in the 1760 os. Yet contemporary ministers, MPs, and journalists viewed these events not as discrete dilemmas but as interrelated parts of a general economic and political picture. It is from this interconnectedness that my book proceeds.

As important, the book resurrects the mid-eighteenth-century question of government objectives in the economy of empire in terms rather different from those that political and imperial historians have previously 
used. Many such scholars have employed mercantilism as the framework for analyzing eighteenth-century conceptions of dominion before 1776 and the publication of Wealth of Nations. A dense historiographic debate has grown up around the meaning of mercantilism in the seventeenth and eighteenth centuries.

This debate presents problems in several respects. First, scholarly sparring on narrow issues often precludes an overall reconstruction of contemporary attitudes toward state involvement in the economy-lots of mercantile trees, no fiscal forest. Second, much of the scholarly discussion has concentrated on the doctrine of mercantilism without reference to policy. Third, imperial scholars, hemmed in by the anachronisms of mercantilism, have paid insufficient attention to eighteenth-century political and economic writers before Adam Smith. The Scottish economist did not create the configurations of mercantilism or modern political economy. He was not even the first to use the term political economy in English; James Steuart had used it some eight years earlier. Smith built on a rich, complex, and at times precocious set of ideas rooted in the

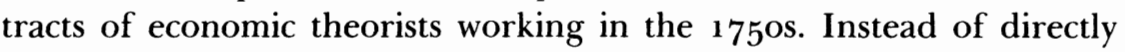
engaging the historiographic controversy about mercantilism, I have concentrated on resurrecting the 1760 ' dialogue about political economy and empire.

In examining the interconnections between imperial economics and politics, this book disturbs the apartheid that has tended to separate economic history from political, social, and cultural history. The economists who practice economic history are rarely concerned with the societal and political contexts in which all the hard numbers of capital formation, urbanization, and total factor productivity growth were generated. Historians of politics and society usually have not investigated how the surrounding economy shaped their subjects. For example, recent historians of British nationalism have been interested in the relation between popular politics and imperial ideology in the middle of the eighteenth century. This is fascinating stuff, but without an understanding of the economy in which these forces interacted, one's view of the connection is eclipsed. How many ships England had in 1716 , in 1739 , and in 1760 to fight imperial wars depended on how much tax revenue the state raised. This in turn was a function of how much wool and glass and Midlands cutlery the nation exported and how many casks of Madeira Britons drank. The state of the economy mattered; it shaped the politics, perspectives, and fate of the British Empire.

The book is divided into six chapters. The first examines how particular 


\section{xii Preface}

aspects of Britain's performance in the Seven Years War crystallized previously amorphous concerns about empire and pushed them into the center of a large public debate about imperial policymaking. The second chapter investigates macroeconomic transitions in the 1760 s and how they shaped lobbying interests concerned with imperial governance. Chapter 3 reconstitutes the interconnections between ministerial objectives in the empire, the emerging field of political economy, and the policy choices that imperial experts confronted. Chapter 4 analyzes the elite political alignments that developed around the issue of imperial management and explores how these ministerial and parliamentary configurations were affected by economic and geopolitical change. Chapter 5 reconstructs Britons' views of their nation's new power and sketches the significance of these attitudes in legislative debates. The final chapter consists of two case studies of policymaking - the repeal of the Stamp Act and the enactment of West Indian free ports in 1766 , and the First East India Regulating Act of 1773 . Both exemplify the fiscal and commercial problems of governing a decentralized empire, and each illustrates the interaction of the economic and political factors that conditioned policy responses.

The new problems and opportunities that accompanied Britain's victory in the Seven Years War informed what went on at the peace negotiating tables in $176_{3}$, and the imperatives of empire formed a subtle, influential structure in which the more prominent constitutional battles of the next decade played themselves out. In India and North America, imperial experts sought divergent solutions to what kind of empire Britain was to have and how to govern and pay for it. Married to these considerations in $176_{3}$, in $178_{3}$, and beyond was the issue of how best to promote national power and plenty. Within a transforming economy and conditioned by the experience of war, Britons struggled to harness the power of commerce to the demands of international ascendancy.

I have lived with this work for some time, and as I prepare the manuscript for publication, I feel as parents must when they send a child to college. I'm sad to see a close relationship change. At the same time, it's gratifying to watch one's offspring assume a fuller existence.

I am hardly the first to use such an analogy. Charlotte Brontë thought all authors grew "tenderly indulgent, even blindly partial to their own." Writing, according to Annie Dillard, is working from one's love and knowledge to produce complex entities that endure. Like parenthood, 
the six years I have spent thinking about and writing this book have been filled with the joy and frustration of creation.

I have not been a single mother. More than a score of libraries, institutions, and colleagues have helped me see this work through to publication. I express my appreciation to the earl of Shelburne for permission to use his collections. I also thank the staffs of the British Library, the Houghton and Widener Libraries, the Kress Library at the Harvard Business School, the Clements Library, the Public Record Office, the Sheffield City Library, the John Rylands Library, the Scottish Public Record Office, the Bodleian Library, and the Bank of England Archives. These women and men showed me much kindness and courtesy.

I am grateful to the Division of Research at Harvard Business School, which provided financial support for research and writing, to the Whiting Foundation, which funded the writing of my doctoral dissertation, and to the Fulbright Fund, the Krupp Foundation, and the Frank Knox Fellowship, all of which helped finance my research in Britain.

I thank three historians, John Brewer, Franklin Ford, and Simon Schama; each brought distinct insights to bear on my work. I am especially grateful to John Brewer. Since 1984 he has turned keen attention to my ideas and their development, with humor and good advice. Franklin Ford offered historical insight and encouragement throughout my time in Harvard University's History Department. Simon Schama has been a constant source of inspiration, expanding my field of historical vision and my sense of literary reconstruction.

Several other scholars, at Harvard and elsewhere, read earlier versions of this work. I am indebted to them for their time and effort. Danny Goldhagen, John Hall, Peter Hall, and John Styles all offered useful suggestions. Philip Lawson read the work for Cornell University Press, giving generously of his time to make recommendations large and small. Several years before it became chapter 5 , Linda Colley reviewed my analysis of perceptions of empire.

Other students of history and national strategy have influenced this book. I thank my Harvard Business School colleagues George Lodge, Cynthia Montgomery, Bruce Scott, Richard Tedlow, and Dick Vietor for their remarks on specific chapters. I am also grateful to the members of the Business History Seminar for advice and input on the first and third chapters. I owe special thanks to Tom McCraw, who read the entire work and offered valuable advice on style and substance. This book is more carefully and incisively crafted than it could possibly have been without him. 
Other talented men and women helped me complete the project. At Cornell University Press, I've been exceptionally fortunate to work with Roger Haydon. For three years he has brought critical insight and literary grace to bear on all aspects of this book. I thank him as well for his wit and humanity. I could not have brought the work to publication without Catherine Reggio, who produced the final manuscript with intelligence and care. She assisted me with the last stages of research, chasing down eighteenth-century documents in Widener Library's labyrinthine stacks. I have profited also from her kindness and encouragement. With precision and organization, Becky Voorheis edited the footnotes and bibliography. Her understanding and support were equally important contributions to the manuscript.

My debts, intellectual and otherwise, to Margaret Talbot are large. For many years she has taken time from her own writing and editorial responsibilities to read my work. On a wide range of issues, her suggestions have improved this book. I am also grateful for the understanding and warmth she has so consistently offered. Judith Livingston helped me clarify my thoughts about the work; I owe her more than I can here say.

If this work is in many respects my child, it owes its development as much to Colin Davis as to me. On this side of the ocean and in England, he has given his time, energy, discernment, and support to me and my scholarly progeny. In a book about eighteenth-century economy and politics, I have not always found it easy to reflect his gentle wisdom and guidance. But they have been with me all along, and I am truly thankful.

Nancy F. Koehn

Cambridge, Massachusetts 
The Power of Commerce 


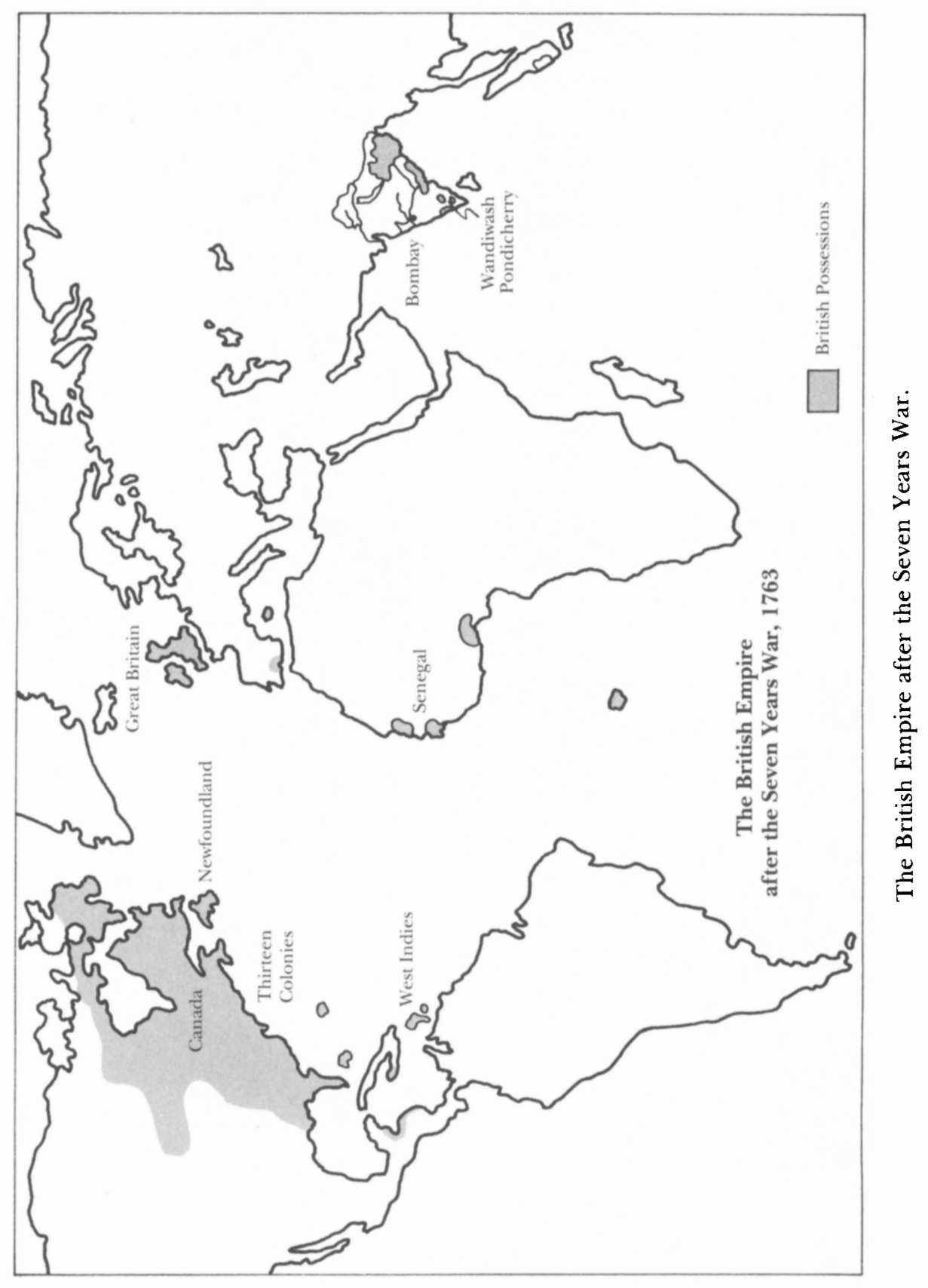

